Normas para a apresentação de originais

Hegemonia - Revista Eletrônica de Relações Internacionais do Centro Universitário Unieuro

ISSN: $1809-1261$

UNIEURO, Brasília, número 14, 2014, pp. 131-171.

Recebido em: 29/8/2014

Avaliado em:14/9/2014

Aprovado em: 18/10/2014

\title{
Breve histórico da imprensa no Brasil: \\ Desde a colonização é tutelada e dependente do Estado
}

Trajano Silva Jardim ${ }^{1}$ e Iolanda Bezerra dos Santos Brandão²

Resumo: O presente artigo explora a atuação dos Meios de Comunicação de Massa na cultura política brasileira, construída desde a colonização do Brasil, em contraponto ao pensamento da "pedagogia do oprimido" de Paulo Freire, leva a população a não compreender e a não definir com clareza as obrigações do Estado com o cidadão. Assim, os governos executam políticas públicas de forma clientelista e não como direito de cidadania das pessoas, pelos impostos que elas pagam. Fazem isso como concessão. E essas práticas são reforçadas pelos discursos funcionalistas da maioria dos jornais, que se posicionam como veículos comunitários integrados e exercem o papel de porta-vozes do poder. $\mathrm{Na}$ redação, adotamos o formato de ensaio e interpretação. Para isto, foi realizada pesquisa em documentação primária a partir das obras de Nelson Werneck Sodré, História da imprensa no Brasil e Bernardo Kucinski, Jornalistas e revolucionários: nos tempos da imprensa alternativa. Também foi consultada literatura especializada no assunto, publicada no Brasil.

Palavras-chave: Colonização do Brasil; Meios de Comunicação de Massa; política brasileira.

Mestrando em Ciência Política no Centro Universitário Unieuro.

Doutora em Psicologia, docente do Unieuro e da Universidade Católica de Brasília. 
Normas para a apresentação de originais

Hegemonia - Revista Eletrônica de Relações Internacionais do Centro Universitário Unieuro

ISSN: $1809-1261$

UNIEURO, Brasília, número 14, 2014, pp. 131-171.

Abstract: This article explores the role of Mass Media in Brazilian political culture built since the colonization of Brazil, as opposed to the thought of "Pedagogy of the Oppressed" by Paulo Freire, leads to people not understanding and not to define clearly the obligations of the state to the citizen. So governments perform public policies clientelist form and not as a right of citizenship of the people, by the taxes they pay. Do it as a concession. And these practices are reinforced by the functionalist discourse of most newspapers, which position themselves as integrated community vehicles and play the role of spokesmen of power. In writing, we adopted the test format and interpretation. For this, research was carried out in primary documentation from the works of Nelson Werneck Sodré, History of the press in Brazil and Bernardo Kucinski, journalists and revolutionaries: the days of the alternative press. Was also consulted the literature on the subject, published in Brazil.

Keywords: Colonization of Brazil; Means of Mass Communication; Brazilian politics.

Introdução

O presente artigo explora a atuação dos Meios de Comunicação de Massa na cultura política brasileira, construída desde a colonização do Brasil. Em contraponto ao pensamento da "pedagogia do oprimido" de Paulo Freire, leva a população a não compreender e a não definir com clareza as obrigações do Estado com o cidadão. Assim, os governos executam políticas públicas de forma clientelista e não como direito de cidadania das pessoas, pelos impostos que elas pagam. Fazem isso como concessão. E essas práticas são reforçadas pelos discursos funcionalistas da maioria dos jornais, que se posicionam como veículos comunitários integrados e exercem o papel de porta-vozes do poder.

Este artigo busca demostrar o quanto a imprensa brasileira, desde sua gênese, é tutelada e dependente do Estado. Mesmo com o advento do capitalismo no Brasil, na Primeira Revolução Industrial, quando as pequenas 
Normas para a apresentação de originais

Hegemonia - Revista Eletrônica de Relações Internacionais do Centro Universitário Unieuro

ISSN: $1809-1261$

UNIEURO, Brasília, número 14, 2014, pp. 131-171.

tipografias de cunho artesanal transformam-se em imprensa-indústria, a imprensa continua subordinada ao Estado. A burguesia, que se apropria dos meios de produção desenvolvidos, transforma-se também em dona das novas formas de comunicação de massa. Os antigos artesãos são excluídos do mercado pelo alto custo dos novos equipamentos, que permitem a transformação dos pequenos boletins de periodicidade e formatos irregulares em jornais diários e com melhor padrão de qualidade. Para esses investimentos, o chamado "baronato da imprensa" recorre aos cofres públicos. Nesse contexto, como podemos observar, a imprensa comporta-se, desde seu surgimento, como "aparelho hegemônico do Estado", atuando como instrumento difusor da ideologia da classe dominante a que ela pertence.

Desta forma, este trabalho se propõe a delinear o desenvolvimento do Brasil em suas instâncias políticas e econômicas e o papel da imprensa brasileira ao longo da história fazendo um recorte compreendido do período Imperial até o governo de transição Tancredo Neves/José Sarney. A análise deste extrato tem como objetivo discutir as nuanças das parceiras ideológicas/econômicas e políticas estabelecidas entre os veículos de comunicação brasileiros e as organizações públicas e privadas nos mais diversos setores de atuações e as emblemáticas consequências dessas parceiras .

Na redação, adotamos o formato de ensaio e interpretação. Para isto, foi realizada pesquisa em documentação primária a partir das obras de Nelson Werneck Sodré, História da imprensa no Brasil e Bernardo Kucinski, Jornalistas e revolucionários: nos tempos da imprensa alternativa. Também foi consultada literatura especializada no assunto, publicada no Brasil.

O Poder dos Meios de Comunicação em Massa

Os Meios de Comunicação de Massa, como subsistemas, estabelecem, por meio do discurso, uma relação de representatividade em que o "sujeito sem voz, ou voz sujeitada à voz-leitora dos jornais" é a forma pela qual o sistema põe em evidência a nova narrativa jornalística, como definem Njaine e Minayo citando Fausto Neto (2002). 
Normas para a apresentação de originais

Hegemonia - Revista Eletrônica de Relações Internacionais do Centro Universitário Unieuro

ISSN: $1809-1261$

UNIEURO, Brasília, número 14, 2014, pp. 131-171.

Na visão de Njaine e Minayo (ibden. 2002) citando Gramsci, o discurso é a principal causa da atividade informacional e alimenta-se da formação da própria hegemonia e das correntes contra-hegemônicas. Assim, o poder capitalista, por intermédio desse fenômeno informacional que é a mídia, tenta manter-se hegemônico. Para isso, tem de estar em diálogo constante com seus contrários e com o meio popular, pelos quais nutre profundos preconceitos.

A classe dominante usa o artifício do diálogo como forma de legitimação e manutenção de seu poder, atuando na diversidade de ideias e de vozes frente à realidade objetiva, mas sempre procurando ressaltar sua visão de mundo.

Apesar disso, vale afirmarmos que, como integrante da atividade social, a mídia trabalha em sentido paralelo ao da ideologia da classe dominante, embora o faça com certo grau de autonomia funcionalista. Isso leva muitos autores a denominarem a mídia "o quarto poder". Por isso, neste momento histórico, parcelas importantes da sociedade travam uma luta em torno da necessidade de normas que definam o papel da mídia no contexto social como instrumento de informação e de formação. Que ela possa mudar o viés de construção de "correntes hegemônicas e contra-hegemônicas", e de controle que liga sua identidade às classes e aos valores dominantes, procurando desconstruir uma ação de mediação sociocultural voltada à legitimação do discurso das classes dominantes.

Nesse contexto, Wolf (1999), com base na Teoria Crítica, afirma que o papel da mídia na informação, na maioria das vezes, responde aos questionamentos das classes eruditas. Essas classes exigem matérias mais abrangentes, aprofundadas e críticas sobre os fatos e relações sociais, embora esses fatos não sejam claramente por elas reconhecidos. Ideologicamente, essa é a função latente e real dos jornais funcionalistas que não são por elas reconhecidos nem conscientemente desejados.

Com a redemocratização do país, os jornais alternativos de resistência perderam seu espaço de vozes das "correntes contrahegemônicas". Surgiram, então, os jornais comunitários, que logo foram apropriados pelos setores hegemônicos, tendendo a repercutirem as ideias 
Normas para a apresentação de originais

Hegemonia - Revista Eletrônica de Relações Internacionais do Centro Universitário Unieuro

ISSN: $1809-1261$

UNIEURO, Brasília, número 14, 2014, pp. 131-171.

dominantes. E, por vezes, com essa atitude, colaborando para a discriminação e a rejeição que perpassam por vários segmentos da sociedade, contra as parcelas mais desfavorecidas ou de classes sociais subalternas.

O papel do veículo alternativo deixou de ser o de uma tomada de posição numa relação desigual de poder, tendo-se em vista que a construção do discurso para transmitir a notícia que atinge um determinado nicho da sociedade está nas mãos dos jornalistas "geralmente de classe média, portanto distanciados espacial e culturalmente da realidade que constitui o seu modo e suas condições de vida" (Njaine e Minayo, 2002, p. 6). Na visão estrutural-funcionalista, de acordo com Wolf (1999), os jornais alternativos passam a priorizar não mais o comportamento, mas a ação social na sua integração aos modelos e valores particulares e institucionalizados, reduzindo, dessa forma, a manifestação humana a uma vinculação de causalidade direta, em que o sistema social é visto como entidade na qual seus diversos setores executam o papel de integração e manutenção do sistema.

Breve histórico da imprensa no Brasil

O objetivo deste artigo é mostrar que a imprensa brasileira, desde sua gênese, é tutelada e dependente do Estado. Mesmo com o advento do capitalismo no Brasil, na Primeira Revolução Industrial, quando as pequenas tipografias de cunho artesanal transformam-se em imprensa-indústria, a imprensa continua subordinada ao Estado. A burguesia, que se apropria dos meios de produção desenvolvidos, transforma-se também em dona das novas formas de comunicação de massa. Os antigos artesãos são excluídos do mercado pelo alto custo dos novos equipamentos, que permitem a transformação dos pequenos boletins de periodicidade e formatos irregulares em jornais diários e com melhor padrão de qualidade. Para esses investimentos, o chamado "baronato da imprensa" recorre aos cofres públicos. 
Normas para a apresentação de originais

Hegemonia - Revista Eletrônica de Relações Internacionais do Centro Universitário Unieuro

ISSN: $1809-1261$

UNIEURO, Brasília, número 14, 2014, pp. 131-171.

Nesse contexto, como podemos observar, a imprensa comporta-se, desde seu surgimento, como "aparelho hegemônico do Estado", atuando como instrumento difusor da ideologia da classe dominante a que ela pertence.

Os primeiro passos

A imprensa brasileira surge tardiamente. Na Europa, em 1609, aparecem as primeiras gazetas impressas, na Alemanha. No Brasil, somente com a vinda de D. João VI, em 1808, começa a circular o jornal Gazeta do Rio de Janeiro. Como não podia ser diferente, ele tem como linha editorial divulgar e difundir os interesses da Coroa, sem conteúdo social. No mesmo ano da chegada da família real ao Brasil, José Hipólito da Costa edita o primeiro jornal de oposição ao domínio português, o Correio Braziliense, impresso na Inglaterra por total falta de liberdade de se o fazer no país.

No Brasil, a Lei de Imprensa antecede a Proclamação e a Independência. Segundo Laner (2000), nessa época, no Brasil Colônia da Corte Portuguesa, não existia legislação referente à matéria. Aplicava-se a Lei Portuguesa de 12 de julho de 1821, posta em execução na Bahia. Essa lei tinha por objetivo conter os excessos da imprensa na livre manifestação de pensamento e de opinião, por meio de um júri, um conselho de sentença denominado Juízo dos Jurados, formado por 24 pessoas escolhidas pelo regente. Sua oficialização deu-se por Decreto de 22 de Novembro de 1823 outorgado por Dom Pedro I. Era a formação do Juizado de Fato ou Júri Escabinado.

O Movimento Constitucionalista Português, de 1820, traz ânimo às forças que priorizam a liberdade à Independência, na esperança de que uma puxe a outra. Segundo Sodré (1999), "Para o desenvolvimento da imprensa brasileira, o movimento de 1820 teve consequências favoráveis". Foram conseqüências que impulsionaram o movimento pró-independência, mudando sua qualidade e encontrando uma imprensa com base mínima para nele influir. Quando desse movimento, "circulavam no Brasil apenas os insípidos Gazeta do Rio de Janeiro e Idade de Ouro do Brasil, periódicos típicos da imprensa áulica". 
Normas para a apresentação de originais

Hegemonia - Revista Eletrônica de Relações Internacionais do Centro Universitário Unieuro

ISSN: $1809-1261$

UNIEURO, Brasília, número 14, 2014, pp. 131-171.

Em agosto de 1821, começa a circular, na Bahia, o Diário Constitucional, primeiro jornal a defender os interesses brasileiros, quebrando a monotonia da imprensa áulica. Mesmo em pleno movimento da Independência, no ano de 1822, o Governo Colonial utiliza forças militares para fechar o jornal nativista $O$ Espelho, do Rio de Janeiro (Sodré, 1999, pp. 51).

Em agosto deste último ano, o da Independência, não podendo vencer pelos argumentos, a prepotência utilizou o seu método normal, suprimindo violentamente o órgão nativista, por assalto militar de que deu notícia $O$ Espelho, do Rio de Janeiro, com a seguinte nota; "O Constitucional era o único periódico que se atrevia a lançar em rosto àqueles tiranos sua arbitrariedade, sua injustiça, sua barbaridade"(Sodré, 1999,p.52).

Com o fim do Governo Joanino, em 1821, D. João VI edita sua última lei contra a imprensa, que, entre outras coisas, exige que todo impressor remeta ao Diretor de Estudos, para verificação, duas provas da obra que esteja sendo impressa. Esse dispositivo, segundo Sodré (1999), não foi levado em conta por aqueles que lutavam pela autonomia, até que o golpe ministerial de outubro, menos de dois meses depois do Ipiranga, arrasou a imprensa de oposição, prova de que mesmo a Independência não via com bons olhos a livre manifestação de pensamento e de opinião. Formalmente, somente em 1827, pelo Decreto de 28 de agosto, a censura foi interrompida.

Segundo Laner, a Lei de Imprensa de 1830 teve a preocupação de regular apenas o artigo 179, parágrafo 40 , da Constituição imposta pelo imperador em 1824. Nela eram mantidas as penas corporais e pecuniárias, com detalhamento sobre o Tribunal de Imprensa, dividido no Júri de Acusação e no Júri de Julgação.

Na opinião de Araújo/Souza, precisou-se de quase três décadas para que surgisse o jornalismo livre no Brasil.

Em 1829, saía, em São Paulo, O Observador Constitucional, de Líbero Badaró, jornalista identificado com ideais liberais. São inúmeros os jornais, folhetos e pasquins do período de 1822 a 1831, principalmente porque havia, um ano antes, 
Normas para a apresentação de originais

Hegemonia - Revista Eletrônica de Relações Internacionais do Centro Universitário Unieuro

ISSN: $1809-1261$

UNIEURO, Brasília, número 14, 2014, pp. 131-171.

sido declarada a independência do Brasil e junto com ela abolida a censura prévia.

Dois jornais importantes são fundados em 1821 e 1827: a Malagueta e a Aurora Fluminense.

Quatro jornais destacam-se nos dois últimos meses do primeiro reinado. São eles: $O$ Buscapé, $O$ Doutor Tirateimas, $O$ novo Conciliador e $O$ Enfermeiro dos Doidos. (Araújo/Souza,2002, p.16).

O fim da censura facilita o aparecimento dos jornais comunitários, informativos de grupos políticos, étnicos e de categorias profissionais: alguns deles defendem a independência e a abolição da escravatura; outros estão ligados a ideias políticas de visão libertária de tendência anarquista; e outros são feministas, que defendem os interesses das mulheres.

Em 1845, nasceu a imprensa social de caráter político no Brasil. Em $1^{\circ}$ de agosto, foi editado o O Socialista, da Província do Rio de Janeiro, em Niterói, desafiando os poderosos representantes da Coroa Portuguesa (Rodrigues, 1996). Até 1900, são publicados 64 tipos de informativo no Brasil, o que ocasiona a prisão e o assassinato ou deportação de centenas de cidadãos ligados àqueles veículos.

Proclamada a República, foi aprovado, em 11 de outubro de 1890, um novo Código Penal que englobou os crimes de imprensa. Promulgada a primeira Constituição Republicana, em 24 de fevereiro de 1891, permaneceram os princípios liberais sobre a atuação da imprensa, tendo sido vetado o anonimato (Laner, 2000).

Na última década do século XIX, no governo provisório de Deodoro da Fonseca, exatamente em 29 de novembro de 1890, é depredado e fechado o jornal $A$ Tribuna. Segundo Sodré (1999), esse fato levou a imprensa da época à mais evidente demonstração de seu desenvolvimento, quando quase todos os órgãos assinaram um duro manifesto de protesto contra o governo.

A imprensa-indústria 
Normas para a apresentação de originais

Hegemonia - Revista Eletrônica de Relações Internacionais do Centro Universitário Unieuro

ISSN: $1809-1261$

UNIEURO, Brasília, número 14, 2014, pp. 131-171.

O século XX é o marco de transição da imprensa no Brasil. A pequena imprensa transforma-se em grande imprensa. As pequenas tipografias e os pequenos jornais de estrutura simples cedem espaço às grandes empresas jornalísticas estruturadas com equipamentos gráficos que permitem ser elevada a produção diária. Mesmo assentados em estrutura de moldes capitalistas, os jornais continuam sem autonomia e são obrigados, de acordo com Sodré,

\begin{abstract}
"a acomodar-se ao poder público que não tem ainda conteúdo capitalista pois o Estado serve principalmente a estrutura pré-capitalista tradicional. O traço burguês da imprensa é facilmente perceptível, aliás, nas campanhas políticas, quando acompanha as correntes mais avançadas, e em particular nos episódios mais críticos, os das sucessões (Sodré, 1999, p. 276).
\end{abstract}

Assim, o jornal como empreendimento individual desaparece das grandes cidades. Torna-se mais fácil adquirir um jornal do que fundar um novo. "É ainda mais prático comprar a opinião do jornal do que comprar o jornal" (Sodré, 1999, p.276).

Essas manifestações precedem os jornais alternativos e comunitários de nossa época. Com a industrialização crescente, a liberdade de imprensa na sociedade capitalista passa a ser condicionada, segundo Sodré, pelo capital, pelos recursos que a empresa dispunha e pelo grau de dependência dela em relação às agências de publicidade. Com o jornal diário fora de alcance, as opiniões divergentes são obrigadas a buscar solução em jornais de baixo custo e periodicidade menor. Começa a era do Tabloide.

Na era pós-republicana, nos governos de Deodoro, Floriano, Hermes da Fonseca, Campos Sales, Afonso Pena e Epitácio Pessoa, a relação imprensa $X$ governo é de conflitos, com fechamento de jornais e morte de jornalistas e demais profissionais da imprensa. Apesar disso, surgem várias empresas jornalísticas. Uma das mais importantes foi o Correio da Manhã, do Rio de Janeiro, que, em 1905, no editorial de seu quinto aniversário, em oposição ao governo de Campos Sales, reafirmando as posições quando do seu lançamento, diz: "Veio para lutar, resoluta e serenamente, em prol dos interesses coletivos sacrificados por uma administração arbitrária e imoral. Venceu por isso" (Sodré, 1999, p.287). 
Normas para a apresentação de originais

Hegemonia - Revista Eletrônica de Relações Internacionais do Centro Universitário Unieuro

ISSN: $1809-1261$

UNIEURO, Brasília, número 14, 2014, pp. 131-171.

Epitácio Pessoa é sucedido por Artur Bernardes, eleito em $1^{\circ}$ de março de 1922, que, desde sua posse, mantém o país, por quatro anos, em estado de sítio. Segundo Sodré (1999), "a situação para a imprensa de oposição ficou tão difícil que levou as forças dominantes a não se interessarem em possuir jornais próprios". Essa situação foi propícia a vários movimentos de contestação. Em 5 de julho, os militares do Forte de Copacabana e da Escola Militar de Realengo iniciam uma rebelião. O movimento é sufocado. Porém, deixa sequelas que levam a outros em pouco tempo. A repressão à imprensa é imediata. Vários jornalistas são presos. Entre eles, Edmundo Bittencourt, do Correio da Manhã, jornal proibido pelo governo de circular de 31 de agosto de 1924 a 20 de maio de 1925, que só volta a ser editado graças a uma Decisão da Justiça, que mantém sua posse. Porém, conforme estabeleceu o despacho do juiz "sem liberdade de divulgar, apenas de circular" (Sodré, 1999, p.364).

Em 1926, Washington Luís assume o governo. A tendência de oposição da maioria da imprensa reduz, cada vez mais, a área de influência governamental. $\mathrm{O}$ novo presidente continua a mesma política das oligarquias, fechando os olhos para a nova situação do país. "O Pensamento de Luís Carlos Prestes" transita na linha tenentista a partir da publicação, nos grandes jornais, dos feitos da Coluna Prestes. E, segundo Sodré, concretiza a aproximação de militares rebelados contra a ordem vigente com políticos civis organizados. Rompe-se o acordo da política café com leite. Essa ruptura vem a se constituir na última fase da preparação contra a situação predominante. A Velha República está nos seus estertores.

Ao arcabouço da política das oligarquias mineiras e paulistas, que já começara a desabar ao fim da Guerra Mundial de 1914, seguiu-se a rebelião de 1924 e a marcha da Coluna Prestes. Vários movimentos militares ocorreram, articulados por militares exilados ou clandestinos e políticos de oposição. Essa movimentação desembocou na sucessão presidencial e nas rebeliões de outubro, no sul e no nordeste. Em 11 de julho de 1929, Getúlio comunicou ao presidente Washington Luís a aceitação de sua candidatura, por indicação do governo de Minas Gerais (ib., 1999).

Minas Gerais, Rio Grande do Sul e Paraíba unem-se contra a candidatura de Júlio Prestes, formando a Aliança Liberal, em agosto de 1929. 
Normas para a apresentação de originais

Hegemonia - Revista Eletrônica de Relações Internacionais do Centro Universitário Unieuro

ISSN: $1809-1261$

UNIEURO, Brasília, número 14, 2014, pp. 131-171.

Lançam a chapa Getúlio Vargas e João Pessoa, Presidente da Paraíba, aproveitando a ruptura da política café com leite - acordo existente entre São Paulo e Minas Gerais, que vinham se alternando no poder desde o primeiro governo civil formado com a proclamação da República, mas que não conseguiram consenso para indicação do nome de Antônio Carlos, governador do estado de Minas Gerais.

Boa parte da imprensa apoia a Aliança Liberal, que agrupa as forças de oposição ao governo, conta com as camadas médias urbanas da sociedade e com nomes do Tenentismo como Siqueira Campos, João Alberto, Juarez Távora e Miguel Costa, todos participantes da Coluna Prestes.

\section{O fim da Velha República}

Realizadas as eleições, em $1^{\circ}$ de março de 1930, Júlio Prestes é vitorioso. Os aliancistas lançam dúvidas sobre os resultados por eles considerados fraudulentos. Políticos e militares, que já estavam convencidos de que a solução do impasse só se definiria pela força, estão, agora, mais certos disso. Eclode o movimento de 1930, em 3 de outubro, após o assassinato de João Pessoa, em Recife. Em 24 de outubro, Washington Luís é deposto pela guarnição do Rio de Janeiro. "A 3 de novembro, Getúlio Vargas recebia o poder das mãos da junta militar que comandara o movimento de 24 de outubro na capital. Iniciava-se o Governo Provisório" (Sodré, 1999, p.373).

O novo governo traz no seu bojo o aprofundamento das velhas contradições da sociedade brasileira. Logo cedo, começam a aparecer fissuras nas forças que se haviam unido para derrubar o governo. De um lado, os que acham que o movimento era uma simples troca de personagens no poder. De outro lado, os que acham que é chegado o momento de impor transformações profundas na sociedade. Os primeiros, mais organizados, aliam-se às forças vencidas, assumem os postos de mando e alijam os últimos de toda parcela de poder.

O governo provisório de Getúlio Vargas dá início a um regime de pleno direito. Entretanto, não está voltado para a democratização do país. Ao 
Normas para a apresentação de originais

Hegemonia - Revista Eletrônica de Relações Internacionais do Centro Universitário Unieuro

ISSN: $1809-1261$

UNIEURO, Brasília, número 14, 2014, pp. 131-171.

contrário, ampliam-se as limitações à liberdade de informação. É um prenúncio do que viria a acontecer com a vigência do Estado Novo, quando, seguindo os passos da Lei Adolfo Gordo, de 1923, a censura prévia constaria de um texto constitucional.

As contradições do novo governo aprofundam-se. Jornais, aliados de primeira hora, vão para a oposição. O primeiro deles, o Correio da Manhã. O mesmo ocorre com políticos que foram preteridos no poder. Em 1932, São Paulo rebela-se, apoiado por figuras importantes de outros estados, como Borges de Medeiros, do Rio Grande do Sul. Esse movimento é uma revolta patrocinada pela oligarquia paulista, que tem como pretexto exigir a reconstitucionalização do país. Mas, na verdade, o que se pretende é o retorno à situação anterior, por meio de eleições dirigidas pelo coronelismo.

Derrotado o movimento e presos os seus principais dirigentes, Vargas concorda em convocar eleições para uma Assembleia Constituinte em maio de 1933. A Constituição começa a vigorar em julho de 1934, com Getúlio sendo eleito presidente por voto indireto, pelo Congresso. Nesse período, marcado por intensa polarização ideológica, forma-se a ALN (Aliança Nacional Libertadora), de tendência de esquerda, e a AIB (Ação Integralista Brasileira), inspirada no nazi-facismo. A ALN é proibida de funcionar em julho de 1935, o que provoca a reação de setores militares que seguiam seu programa político. Nesse ambiente radicalizado, eclode, em novembro de 1935, o movimento liderado pelos comunistas de Luís Carlos Prestes. Esse é o mote que Getúlio precisa para levar adiante suas pretensões de permanecer no poder.

O Estado Novo

Usando-se como pretexto o combate a um suposto golpe comunista, na verdade uma trama forjada no interior do próprio poder denominada Plano Cohen, as eleições marcadas para 1938 são suspensas. Em 10 de novembro de 1937, Vargas dá o golpe. Fecha o Congresso Nacional e anuncia a promulgação de nova Constituição em substituição à de 1934, inspirada na Constituição autoritária da Polônia. Os jornais dão-lhe o nome de $A$ Polaca. Nessa Carta, está prevista a extinção dos partidos políticos e uma série de medidas para reprimir as oposições. Como não podia deixar de ser, o poder discricionário volta-se contra os meios de comunicação, abolindo a liberdade de expressão 
Normas para a apresentação de originais

Hegemonia - Revista Eletrônica de Relações Internacionais do Centro Universitário Unieuro

ISSN: $1809-1261$

UNIEURO, Brasília, número 14, 2014, pp. 131-171.

garantida pelo Decreto no 24.776 que, embora contrariasse certos preceitos, merecia algumas apreciações positivas (Laner, 2000).

Em 1939, Vargas cria o DIP (Departamento de Imprensa e Propaganda), dirigido pelo jornalista Lourival Fontes, que tem a função de centralizar coordenar, orientar e superintender a propaganda nacional, interna ou externa (...) fazer censura do Teatro, do Cinema, de funções recreativas e esportivas (...) da radiodifusão, da literatura (...) e da imprensa (...) promover, organizar, patrocinar ou auxiliar manifestaçôes cívicas ou exposições demonstrativas das atividades do governo (Cartilha interna do DIP, 1939, CPDOC-FGV).

A segunda Guerra Mundial traz reflexos para a política cultural do Brasil. É a época da entrada gradativa do american way of life nos costumes da sociedade brasileira. Isso graças a um cuidadoso plano de conquista que faz parte da estratégia dos Estados Unidos de promover a cooperação interamericana e a solidariedade hemisférica para barrar a influência alemã no país.

É criada a Agência Nacional, responsável pelo fornecimento de $60 \%$ das matérias publicadas na imprensa, dando destaque aos valores nacionalistas e à organização do Estado. É uma propaganda essencialmente ideológica distribuída gratuitamente ou como notícias subvencionadas. Isso dificulta 0 trabalho das empresas jornalísticas privadas, que têm impedido seu direito de informação livre e independente. Assim, o DIP/Agência Nacional tornam-se de fundamental importância para propagação dos "valores pan-americanos" e manutenção da ditadura Vargas até 1945 (CEPEDOC-FGV, 2004).

Além da forte censura exercida sobre a imprensa, cuja maioria esmagadora, principalmente no Distrito Federal, opõe-se a Vargas, é atribuído aos meios de comunicação o caráter de serviço de utilidade pública, o que obriga todos os órgãos a publicar comunicados do governo. O veículo de comunicação que não cumprisse essa exigência levaria seu diretor à prisão. $A$ execução dessas medidas fica a cargo do DIP, que passa, por outra imposição do regime, a encarregado do registro dos jornais e dos próprios jornalistas.

Com essas ações, a ditadura varguista dá o primeiro passo para eliminar vários jornais. Em 1940, o governo garroteia de vez a imprensa, com o 
Normas para a apresentação de originais

Hegemonia - Revista Eletrônica de Relações Internacionais do Centro Universitário Unieuro

ISSN: $1809-1261$

UNIEURO, Brasília, número 14, 2014, pp. 131-171.

decreto que exige o registro anual no DIP, para importação de papel. Nesse período, vários jornais são impedidos de circular e centenas não obtêm registro. Um dos mais atingidos é o $O$ Estado de São Paulo. Seu proprietário, Júlio de Mesquita Filho, exila-se e o jornal fica sob intervenção.

Apesar do severo controle, surge a imprensa de resistência, que publica jornais, folhetins e tabloides. Nesse período, circulam o Liberdade, no Rio de Janeiro, o Folha Dobrada, editado por estudantes da USP, em 1939, e o Resistência, em 1944. Levando-se em conta essa situação de rigorosa censura, é natural que a derrubada da ditadura de Vargas passe, prioritariamente, pela imprensa. Em outubro de 1943, a ditadura sofre um duro golpe. Os políticos de Minas Gerais elaboram um documento o "Manifesto dos Mineiros" repudiando o Estado Novo. Em 1944, chegam relatórios da FEB, da guerra, que manifestam o desejo de redemocratização do país (Koshiba, CPDOC-FGV, 2000).

O fim do Estado Novo

Em fevereiro de 1945, o O Globo e o Correio da Manhã dão o golpe mortal na censura à imprensa. O primeiro, com a publicação de uma entrevista concedida por Virgílio de Melo Franco, um dos líderes da Revolução de 1930 que rompera com o regime; e com o lançamento da candidatura do Brigadeiro Eduardo Gomes à Presidência. O segundo, com uma entrevista de José Américo ao jornalista Carlos Lacerda, com posição frontalmente anti-ditatorial. Daí em diante, vários fatores contribuem para uma crise maior que culmina com a queda de Vargas e do Estado Novo, em outubro de 1945 (Almanaque Folha Online, Internet, 2004).

Após a Segunda Guerra Mundial, com a volta da democracia ao Brasil, a Constituição de 1946 restabelece o Decreto n 24776, de 1937, que regulava a liberdade de imprensa. Essa norma não traz grandes avanços. Porém, permite aos jornais - inclusive aos menores, comunitários e alternativos - maior liberdade de circulação, não permitida com tanta abrangência no Estado Novo, quando esse instituto era pró-forma. Embora essa Constituição, a quarta 
Normas para a apresentação de originais

Hegemonia - Revista Eletrônica de Relações Internacionais do Centro Universitário Unieuro

ISSN: $1809-1261$

UNIEURO, Brasília, número 14, 2014, pp. 131-171.

republicana, tenha mantido a federação e o presidencialismo, como a de 1934, foge bastante às linhas doutrinárias de 1891.

O período de redemocratização traz uma liberdade aparente para a imprensa e os meios de comunicação. No plano internacional, o presidente Dutra insere-se nos quadros da Guerra Fria, estabelecida a partir de 1947 com a Doutrina Truman. O governo brasileiro define-se no plano da política internacional como aliado preferencial dos Estados Unidos. Em setembro de 1947, é assinado o tratado de assistência mútua entre os dois países. Com isso, o Brasil rompe relações com a União Soviética, ao mesmo tempo em que o governo endurece suas relações com setores da imprensa de opinião mais à esquerda ou progressista. O Partido Comunista do Brasil, chefiado por Luís Carlos Prestes, é declarado ilegal, seus parlamentares cassados e os jornais fechados (D'Araujo, CPDOC-FGV, 2001).

Novamente Vargas

Getúlio Vargas volta à Presidência da República como ele próprio declara: "nos braços do povo". Nessa eleição, concorreram quatro candidatos. Entre eles estava o Brigadeiro Eduardo Gomes, principal adversário de Getúlio. Depois da eleição, surge na imprensa a expressão "cristianizar", em virtude da decisão da maioria do PSD, partido do candidato Cristiano Machado, de apoiar Getúlio. A partir daí, toda candidatura que não tem o apoio de todo o partido é considerada "cristianizada".

A eleição de 1950 é um marco de transição para a imprensa brasileira. Num encontro com Getúlio, o jornalista Samuel Wainer comprometera-se a se engajar na sua campanha presidencial em todo o Brasil. Com a vitória de Vargas, Wainer funda o jornal Última Hora, com financiamento do novo governo.

O Última Hora transforma-se no maior fenômeno nacional de circulação nos maiores estados brasileiros. Esse sucesso traz na sua esteira uma era de ampla liberdade de imprensa. Inclusive o Partido Comunista, apesar de oficialmente ilegal, edita seu jornal diário em vários estados. Muitos jornais 
Normas para a apresentação de originais

Hegemonia - Revista Eletrônica de Relações Internacionais do Centro Universitário Unieuro

ISSN: $1809-1261$

UNIEURO, Brasília, número 14, 2014, pp. 131-171.

alternativos, de baixo custo, no formato tabloide, de várias tendências são editados nesse período.

O $3^{\circ}$ Governo Vargas começa no momento em que o capitalismo se reorganiza, tendo como centro os Estados Unidos. $O$ processo de industrialização facilitado pela Segunda Guerra Mundial é anulado. O imperialismo retoma seu vigor e a reconquista do mercado brasileiro é empreendida. A política econômica de Vargas, marcadamente nacionalista, choca-se com os interesses imperialistas, principalmente dos americanos. $O$ monopólio do petróleo, a mais significativa decisão do governo, não agradou aos capitalistas norte-americanos. O Governo Eisenhower cancela unilateralmente $o$ acordo de desenvolvimento entre Brasil e Estados Unidos.

Essa fase é, também, um momento de grandes embates na imprensa brasileira. O Última Hora, com o apoio integral de Vargas, transformase, em curto período, em uma das maiores empresas jornalística do país. Isso assusta os jornais tradicionais. $O$ escândalo deflagrado pelo suposto favorecimento de Getúlio a Samuel Wainer torna público que outras empresas jornalísticas - o Diários Associados e o jornal O Globo, entre elas - haviam-se aproveitado de créditos do governo tanto quanto o Última Hora. Este, por mais de uma década, foi o maior jornal de cunho populista do Brasil (Araújo e Souza, 2003).

O Governo Vargas, como era de se esperar, começa a sofrer forte oposição dos conservadores apoiados por grupos estrangeiros, principalmente norte-americanos. Carlos Lacerda, proprietário do jornal $A$ Tribuna da Imprensa, leva a cabo uma campanha violenta contra Getúlio. A situação chega ao auge em 23 de agosto, com o Exército colocando-se contra o presidente, exigindo sua renúncia. Na manhã de 24 , depois de escrever uma cartatestamento, Getúlio suicida-se (D'Araujo, CPDOC-FGV, 2001).

Nos dezesseis meses que se seguem ao suicídio de Vargas, o Brasil vive mais um período de turbulência política. Com isso, a imprensa, que exerce uma pesada carga oposicionista, principalmente os jornais do Rio de Janeiro, cria um clima que tem influência na aprovação da Lei de Imprensa no 2.083, de 12 de novembro de 1953. Esta, por sua estrutura técnica, é considerada retrógrada se comparada ao Decreto n 24.776/34 restabelecido em 1945. 
Normas para a apresentação de originais

Hegemonia - Revista Eletrônica de Relações Internacionais do Centro Universitário Unieuro

ISSN: $1809-1261$

UNIEURO, Brasília, número 14, 2014, pp. 131-171.

Nesse período de transição entre o Governo Provisório e as eleições de 1956, ocorrem várias crises institucionais. As forças getulistas elegem Juscelino Kubitschek de Oliveira, apoiadas pelo PSD e pelo PTB. Inconformadas com a derrota, as forças antigetulistas, tendo à frente a União Democrática Nacional - UDN, reagem à vitória de Juscelino e tentam impedir sua posse. 0 então ministro da Guerra, General Henrique Teixeira Lott, por meio de uma ação militar que ele chamou de "golpe preventivo", garantiu a posse do presidente eleito.

A política desenvolvimentista

Com a ascensão de Juscelino Kubitscheck à Presidência da República, o seu modelo desenvolvimentista devolve ao povo brasileiro a autoestima, a euforia e a crença de valor. Isso se reflete na democracia e na liberdade de expressão e de informação. Criam-se condições para se aumentar, ainda mais, o número de veículos de comunicação impressa, o que promove uma maior participação da população nos ideais de crescimento do país. Essa fase de liberdade política e de imprensa, evidentemente, não tem a simpatia das forças conservadoras brasileiras, que consideram que esse processo coloca em risco os seus interesses políticos e econômicos.

Por sua forma de condução política, Juscelino tem uma relação de simpatia com a grande imprensa e no meio intelectual. Nesse período, surgem vários veículos de informação de circulação nacional. Os mais importantes são as revistas Manchete e Fatos \& Fotos, editadas pelo grupo Bloch Editores, de propriedade dos irmãos Bloch, amigos de JK. Também o grupo jornalístico de Samuel Wainer, aproveitando a fase de crescimento econômico e de liberdade no país, regionaliza, para São Paulo e Rio Grande Sul, a edição de seu principal título, o Última Hora, e começa a editar o Flan, um jornal de amenidades voltado para assuntos culturais e do cotidiano.

No campo do desenvolvimento, o Governo JK traz transformações de grande alcance, principalmente na economia, que tem como base 0 "desenvolvimento econômico industrial". Essa política desenvolvimentista, com 
Normas para a apresentação de originais

Hegemonia - Revista Eletrônica de Relações Internacionais do Centro Universitário Unieuro

ISSN: $1809-1261$

UNIEURO, Brasília, número 14, 2014, pp. 131-171.

base na utilização do Estado como indutor do desenvolvimento, a exemplo da política implantada por Vargas, estimula o empresariado nacional e, ao mesmo tempo, cria condições favoráveis à entrada do capital estrangeiro, seja na forma de empréstimos, seja na forma de investimento direto. Com o objetivo de auxiliar e integrar o Nordeste ao seu projeto de desenvolvimento e ao mercado nacional, Juscelino cria a Superintendência para o Desenvolvimento do Nordeste (Sudene). Também abre caminho para a indústria automobilística, com a criação do GEIA, Grupo de Estudos da Indústria Automobilística. Este organismo constituiu-se no que seria, nos anos seguintes, a viga mestra da industrialização do país, não obstante todas as distorções econômicas provocadas posteriormente.

O esforço do governo para alterar a fisionomia econômica do Brasil desenvolve a indústria e a economia diversifica-se. Porém, a tentativa de eliminação das diferenças econômico-regionais, com a criação da Sudene, não tem saldo positivo. $O$ desenvolvimento do centro-sul acelera-se, aumentando, ainda mais, as disparidades. Isso provoca o êxodo em massa do campo para a cidade, modificando a composição social dos grandes centros urbanos. 0 resultado é o aumento da pobreza e a proliferação das favelas. Esses desequilíbrios precedem e impulsionam as grandes crises que culminam com o movimento de 1964.

Apesar do grande apoio popular e da sustentação da imprensa e dos meios intelectuais, o Governo de Juscelino é alvo de ferrenha campanha dos grupos de oposição dentro e fora do Congresso. Alguns jornais, tendo como ponta de lança o $A$ Tribuna da Imprensa, do deputado Carlos Lacerda, e a União Democrática Nacional (UDN), tentam, a todo custo, impedir a implementação do Plano de Metas do governo, que tem como objetivo principal a construção da nova capital. As mesmas forças que sempre se opuseram ao desenvolvimento independente do país agrupam-se no que a imprensa denomina "banda de música udenista". E conspira abertamente, apesar do estilo desenvolvimentista de Juscelino Kubitscheck ser o precursor do pleno enquadramento do Brasil às novas exigências do capitalismo internacional, que tem os Estados Unidos como centro hegemônico, política ajustada à linha mestra do capitalismo de organização das multinacionais, que transforma o caráter de dominação imperialista. O Brasil passa de exportador de capitais a 
Normas para a apresentação de originais

Hegemonia - Revista Eletrônica de Relações Internacionais do Centro Universitário Unieuro

ISSN: $1809-1261$

UNIEURO, Brasília, número 14, 2014, pp. 131-171.

exportador de bens de consumo, com a internacionalização do mercado brasileiro, tendo como resultado a dependência econômica do país (Flor \& Ramos, Correioweb, Internet, 2004).

Jânio Quadros no poder

Em maio de 1959, Ivan Hasslocher, agente de grupos internacionais, junta-se a empresários brasileiros e estrangeiros ligados ao Royal Bank of Canadá, ao Bank of Boston e ao First National City Bank e cria o Instituto Brasileiro de Ação Democrática - IBAD. A entidade tem por objetivo combater o estilo populista do Governo Juscelino. Mas sua ação política principal é combater o comunismo. O IBAD tem participação fundamental na campanha presidencial de 1960, quando é eleito Jânio Quadros. Essa eleição tem o maior gasto em publicidade até então visto. $O$ país é inundado, de norte a sul, pela "Campanha da Vassoura".

Com a renúncia de Jânio Quadros e a consequente posse de João Goulart, em 1961, acirram-se, ainda mais, os ânimos. Na campanha de 1962, o IBAD cria a Ação Democrática Popular - Adep, com fins eleitorais. A Adep canaliza recursos para os candidatos contrários a Jango e busca a "adesão" de setores da imprensa para divulgar seus programas de conteúdo anticomunistas. 0 jornal $A$ Noite é alugado e, por 90 dias, sua linha política muda radicalmente. Em 20 de dezembro de 1963, com o encerramento dos trabalhos de uma CPI, conclui-se que o dinheiro recebido pela entidade provinha de firmas norteamericanas. Por esse motivo, o IBAD e a Adep são dissolvidos pelo Congresso (CPDOC-FGV, 2004).

A maioria dos jornais comerciais - Correio da Manhã, Jornal do Brasil, Última Hora, Correio Braziliense e Zero Hora - manifesta-se contra o veto dos ministros militares, que pretendem impedir a posse de João Goulart. Enquanto isso, o $O$ Estado de São Paulo e o $O$ Globo são contrários à ascensão de Jango à Presidência. $O$ jornal paulista manifesta-se abertamente em favor da convocação das Forças Armadas, para que elas impeçam que setores 
Normas para a apresentação de originais

Hegemonia - Revista Eletrônica de Relações Internacionais do Centro Universitário Unieuro

ISSN: $1809-1261$

UNIEURO, Brasília, número 14, 2014, pp. 131-171.

subversivos assumam o poder. Mas essa posição altera-se, quase de imediato, devido à radicalização das posições políticas que marcam o Governo Jango.

No decurso da luta pelo fim do regime parlamentarista, quase toda a imprensa vai-se deslocando para o lado dos grupos e movimentos que defendem a derrubada do Governo Constitucional. Poucos jornais ficam ao lado da legalidade e pela convocação do plebiscito. São eles: Última Hora, Diário Carioca, Semanário e Novos Rumos, este editado pelo Partido Comunista. Os demais constituem-se em portadores da mensagem do golpe militar contra Goulart (Abreu, CPDOC-FGV, 2004).

O Executivo consegue aprovar a proposta de convocação do plebiscito e o "não" ao parlamentarismo obtém cerca de nove milhões de votos, contra aproximadamente dois milhões de "sim". O parlamentarismo chega ao fim. Se, por um lado, é uma vitória do governo, por outro funciona como senha para os conservadores. Esses já falam, abertamente, em usar a força para derrubar o presidente. Não o fazem de imediato porque os militares não deixam os quartéis, ainda ressabiados com o fiasco de 1961.

Nesse período, embora ele seja conturbado, a imprensa voltada aos interesses nacionais vive ares de liberdade. A campanha pelas Reforma de Base é intensa. Os sindicatos, a partir dos seus jornais corporativos, procuram conscientizar seus associados e a população em geral da necessidade de mudanças na estrutura social do país. Esse estágio de liberdade vai até $1^{\circ}$ abril de 1964, quando a democracia é novamente interrompida pelo golpe militar. 0 jornal Última Hora e muitos outros são impedidos de circular. É imposta a censura prévia aos grandes jornais.

O golpe militar de 1964

Duas visões políticas confrontam-se com propostas diferenciadas para o país. A visão progressista, com as "reformas de base", e a modernização conservadora. Essas duas vertentes sempre estiveram em confronto nas crises políticas da década de 50, que se refletiram até o início da década de 60 . A renúncia de Jânio Quadros e a posse de João Goulart vêem mostrar o 
Normas para a apresentação de originais

Hegemonia - Revista Eletrônica de Relações Internacionais do Centro Universitário Unieuro

ISSN: $1809-1261$

UNIEURO, Brasília, número 14, 2014, pp. 131-171.

esgotamento do modelo econômico e dos caminhos trilhados pelo processo de transformação do capitalismo brasileiro.

Sob esse amplo espectro denominado "reformas de base" está assentado um conjunto de propostas, as reformas bancária, fiscal, urbana, administrativa, agrária e universitária, além do direito a voto aos analfabetos e às patentes subalternas das forças armadas. Também estão incluídas medidas nacionalistas com uma intervenção maior do Estado no setor econômico e o controle dos investimentos estrangeiros no Brasil, estabelecendo-se a regulamentação das remessas de lucro para o exterior. A reforma agrária é o carro-chefe das reformas. Com essa política, o governo visa eliminar os conflitos pela posse da terra e garantir o acesso à propriedade a milhões de camponeses sem terra. Juntamente com essas medidas, o Governo João Goulart propõe uma política de independência em relação às grandes potências, em particular aos Estados Unidos, defendendo a autodeterminação dos povos e a não ingerência nos assuntos internos de cada país.

Ao mesmo tempo, as escolas de formulação da doutrina militar começam a mostrar as transformações como inevitáveis. Nesse sentido, 0 General Antônio Carlos Murici, representante do setor militar tradicionalista, afirma: "para o bem-estar do povo brasileiro, é necessário modificar-se a estrutura socioeconômica do Brasil" (Dias, CEPDOC-FGV, 2004). Nenhum setor social tem dúvida quanto às origens da crise que o país vivencia. Estamos diante de dois projetos antagônicos. Se o governo Jango, com seus aliados, não fizer as reformas de base, sem dúvida os conservadores as farão a seu modo.

Apesar disso, a conspiração continua. No Congresso, formam-se dois blocos parlamentares: o Frente Parlamentar Nacionalista (FPN) e o Aliança Democrática Parlamentar (ADP). Os militares tomam como seu braço civil de organização o Instituto de Pesquisas e Estudos Sociais (IPÊS), criado em 1961, ainda no Governo Jânio Quadros, por empresários representantes do setor moderno da classe dirigente brasileira. O IPÊS torna-se o laboratório de formulação de um programa político e econômico. Seu objetivo principal é rearticular mecanismos de acumulação capazes de desenvolver o capitalismo brasileiro, em bases modernas, elevando-o a um estágio mais integrado às suas próprias necessidades de desenvolvimento. Constrói-se um programa de 
Normas para a apresentação de originais

Hegemonia - Revista Eletrônica de Relações Internacionais do Centro Universitário Unieuro

ISSN: $1809-1261$

UNIEURO, Brasília, número 14, 2014, pp. 131-171.

reformas, de cunho conservador, porém extremamente ousado em que se sugere, inclusive, a realização de uma reforma agrária.

O movimento militar conta com o apoio explícito do governo americano, que, desde o início, não tinha qualquer simpatia pelo Governo de João Goulart. Porém, enfrenta uma dificuldade estratégica: as duas correntes principais não formam uma unidade - a dos "modernizadores", cujo alto comando era composto pelos Generais Castelo Branco, Golbery do Couto e Silva, Ademar Queirós e Ernesto Geisel, e a dos "tradicionalistas", ou "linha dura", dos Generais Costa e Silva, Siseno Sarmento, Muniz Aragão e Antonio Carlos Murici. Essa divisão permite que um General desconhecido e sem qualquer influência na caserna desencadeie, "intempestivamente" e de forma individual, o golpe de $1^{\circ}$ de abril de 1964, que estava previsto para acontecer entre os dias 4 e 8 de abril.

A posição de submissão do presidente do Senado, Auro Moura Andrade, que de imediato decreta a vacância do governo com o presidente João Goulart ainda em território brasileiro, dando posse ao presidente da Câmara, Ranieri Mazzilli, o apoio imediato dos Estados Unidos ao novo governo e a dispersão completa da base de apoio do Governo de Jango, impossibilitam qualquer reação contrária ao movimento golpista que, naquele instante, não tem uma definição explícita do rumo político a ser seguido (Dias, CEPDOC-FGV, 2004).

Nesse primeiro momento, o centro do poder golpista transforma-se numa "Hidra de Lerna", com diversas cabeças. Cada setor militar arvora-se em condutor da vitória. Os "tradicionalistas", também denominados "tropeiros" por Hélio Gaspari, e os "modernistas esguianos" civis e militares, divididos entre si, travam uma luta aguerrida pelo espólio político do movimento.

Enquanto não se define qual cabeça da "Hidra de Lerna" deverá exercer o poder de fato, os ministros militares constituem uma junta governativa formada pelas três armas. Essa junta, em 9 de abril, representando o Comando Supremo da Revolução, baixa o primeiro ato institucional, o AI-1. Após, há a divulgação do segundo ato e, nele, "a revolução investia no exercício do Poder Constituinte". Essa norma não é legitimada pelo Congresso. A partir dela, o Congresso é que é legitimado. 
Normas para a apresentação de originais

Hegemonia - Revista Eletrônica de Relações Internacionais do Centro Universitário Unieuro

ISSN: $1809-1261$

UNIEURO, Brasília, número 14, 2014, pp. 131-171.

A grande imprensa e o golpe militar

Nos primeiros dias do golpe, a grande imprensa, complacente com a nova situação, exorta o novo governo a "limpar o país", pondo fim à corrupção política e administrativa. A exceção é o Correio da Manhã que, em 3 de abril, como voz discordante, no meio das comemorações da vitória do movimento militar, publica um editorial intitulado "Terrorismo Não", contrapondo-se às manifestações de arbítrio que se desenham.

Com a obstrução dos espaços democráticos de manifestação, o golpe militar, logo de início, destrói o jornal Última Hora, o principal veículo de massas ligado ao campo popular e que tem nos seus quadros dezenas de jornalistas de espírito crítico voltado para os interesses nacionais. Por isso mesmo, o Última Hora é considerado, pelas famílias tradicionais proprietárias da imprensa, um intruso. O jornal de Samuel Wainer havia derrotado o baronato da imprensa em vários campos: no ideológico, com sua linha nacionalista que quebrou a homogeneidade do discurso tradicional; no sentido da forma, ao revolucionar o jornalismo brasileiro; no mercadológico, conquistando o maior número de leitores; e no institucional, ao conseguir altos financiamentos do Estado, antes exclusivos do baronato (Kucinski, 2003).

A destruição do Última Hora, em abril de 1964, não está inserida somente no contexto geral de repressão. Ela é o ato final de uma ofensiva criminosa das oligarquias tradicionais da imprensa, na divisão de seus despojos. As oficinas do Rio de Janeiro são depredadas e fechadas. E, em São Paulo, o boicote econômico, capitaneado pela Federação do Comércio e pela Fiesp, obrigou o jornal a fechar as portas (ib., 2003).

A eleição de Castelo Branco é uma saída entre a ditadura escancarada dos "tropeiros" e a ditadura intelectual dos "modernistas". Assim, nada está definido quanto aos rumos políticos ou quanto a qual linha receberia o comando. Agora, trata-se de se debelar a desordem da rebelião, mantendose intactos os degraus de comando e da hierarquia nos quartéis. Essa não é uma tarefa fácil e Castelo sabe disso. Segundo Gaspari (2002), sua eleição teve 
Normas para a apresentação de originais

Hegemonia - Revista Eletrônica de Relações Internacionais do Centro Universitário Unieuro

ISSN: $1809-1261$

UNIEURO, Brasília, número 14, 2014, pp. 131-171.

a oposição de Costa e Silva, que queria "assumir tudo" no primeiro momento. No dia 10 de abril, numa atitude audaciosa, Costa e Silva, de quem o Brasil nunca ouvira falar, envia um documento para todos os comandos militares proclamando-se Comandante Geral do Exército. Tão verdade quanto a tradição da data do documento.

As várias cabeças da "Hidra" ainda estão bem vivas e não seriam eliminadas tão cedo. Mourão Filho, "uma espécie de oportunista e fanfarrão", na opinião do Departamento de Estado Norte americano, empurrado para a presidência da Petrobrás é impedido de assumir por um funcionário de carreira da empresa, que está descontente com o desfecho do movimento. Os Inquéritos Policiais Militares são conduzidos de acordo com os comandos militares de cada região. De 1964 até 1967, o presidente Castelo Branco exerce uma ditadura. E a "linha dura" luta para que ela vá o mais longe possível (ib., 2002). Assim, segundo Heitor Cony, na sua coluna do Correio da Manhã, de 7 de maio de 1964:

Para atender a essa gente, a todos os Joões de tal que não voltaram ou não voltarấo um, dia, espero merecer a atenção e o respeito de todos. E preciso que alguém faça alguma coisa. E já que não se pode mais pedir justiça, peço caridade.

A violência estabelece um estado de anarquia. Generais, alguns comandantes de guarnições da Vila Militar rebelam-se contra Castelo, em 1965. Em 15 de março de 1967, Costa e Silva, em aliança com a "linha dura", é eleito Presidente da República. Em 1968, a morte do estudante Edson Luís, o discurso do deputado federal Márcio Moreira Alves, as agitações que a ele se seguem e a resistência do Congresso em cassá-lo servem de motivação para que a cabeça da "Hidra" linha dura assuma o comando e escancare de vez a ditadura.

Mesmo com a ditadura plena, o movimento de resistência continua, com os estudantes na vanguarda da luta e vozes discordantes de parlamentares no Congresso Nacional. As eleições dos governadores das capitais, em 1966, são um momento de demonstração de repúdio da sociedade ao regime. O MDB - Movimento Democrático Brasileiro, partido de contestação consentido pela ditadura consegue eleger seus candidatos em Minas e no Rio de Janeiro. Isso é também um alerta para o governo militar. Os "tropeiros", 
Normas para a apresentação de originais

Hegemonia - Revista Eletrônica de Relações Internacionais do Centro Universitário Unieuro

ISSN: $1809-1261$

UNIEURO, Brasília, número 14, 2014, pp. 131-171.

golpistas mais comprometidos com a repressão, passam a se articular e a exigir medidas mais efetivas contra "a subversão comunista" que, na visão daquele setor, ainda não foi derrotada.

Em 13 de dezembro, é editado o famigerado AI-5. A direita brasileira, que teve forças para construir um regime que cassou mandatos, interveio em sindicatos, aposentou, baniu e torturou professores e funcionários públicos, censurou e fechou jornais, não consegue garantir a disciplina nos quartéis que the deram sustentação. É o golpe dentro do golpe. (Gasparian, 2002).

Nesse segundo momento, o regime chega ao auge da repressão, com centenas de prisões. A denúncia pela imprensa está reduzida ao Correio da Manhã, que bravamente resiste no direito de informar, e eventualmente a mais um ou dois veículos de informação regionais. A comunidade criada pelo General Golbery do Couto e Silva, que tem como centro o Serviço Nacional de Informações (SNI), ligado à Presidência da República, é a marca da nova arma na estrutura militar brasileira. Ela será um instrumento de grande valia no processo de repressão e de controle, principalmente no campo da cultura e liberdade de expressão e opinião.

Essa fase de repressão é embrionária para o aparecimento dos veículos "integrados ao sistema", de acordo com a teoria funcionalista, em que os meios de comunicação de massa figuram como um subsistema do sistema complexo que forma a sociedade como um todo (Alves, 2004). Ela perdura, não obstante a redemocratização do país com a Constituição de 1988 e da nova Lei de Imprensa. Mas, ao mesmo tempo, faz surgir movimentos de resistência ao modelo implantado pelos militares de censura e repressão aos meios de comunicação.

A edição do AI-5 sinaliza para as elites dominantes que 0 golpe entrara num período de consolidação. Com isso, a grande imprensa adapta-se rapidamente às novas condições: demite seus jornalistas mais visados e críticos. O Correio da Manhã, o único que não se submete ao regime, sofre dois atentados. Seu diretor-superintendente, Oswaldo Peralva, é preso por uma semana, em dezembro de 1968, e, em janeiro de 1969, são presos o diretor Nelson Batista e a proprietária Niomar Muniz Sodré. É o único caso nas relações 
Normas para a apresentação de originais

Hegemonia - Revista Eletrônica de Relações Internacionais do Centro Universitário Unieuro

ISSN: $1809-1261$

UNIEURO, Brasília, número 14, 2014, pp. 131-171.

entre o regime militar e os barões da imprensa. Em março de 1969, o jornal pede concordata e, em setembro, é arrendado por terceiros (Kucinsk, 2003).

Apesar dos acordos estabelecidos com os "tropeiros" da linha dura, o general Costa e Silva não é um integrante convicto do grupo. Ele é uma das cabeças da "Hidra de Lerna" e tem um projeto de poder pessoal. Os radicais sabem disso e não estão dispostos a abrir mão do espaço conquistado. Intensificam a repressão e a pressão sobre o governo.

Em meio a essa atmosfera de tensão permanente, em 26 de agosto, Costa e Silva mostra os primeiros sintomas de trombose cerebral. Em 30 de agosto, com o agravamento da doença do presidente, o Alto Comando das Forças Armadas reúne-se e edita o AI-12, por meio do qual uma junta constituída pelos ministros do Exército, da Marinha e da Aeronáutica assume interinamente a presidência da República (Vera Calicchio/Dora Flaksman, CPDOC-FGV, 2004).

O silêncio imposto à imprensa é fundamental para o sucesso do combate à guerrilha urbana, que promove ações espetaculares por todo o ano de 1969, culminando-as com o sequestro do embaixador americano Charles Burke Ellbrick, em 4 de setembro. Segundo Kucinsk (2003), os jornais pouco falaram do sequestro do embaixador e da doença de Costa e Silva. A grande imprensa preferia omitir-se, também por uma identificação de classe. Nessa época, a televisão começa a se transformar em grande veículo de massas e inicia-se a ascensão do Jornal Nacional da TV Globo, com a monopolização do espaço informativo a serviço do sistema. Aparecem vários projetos jornalísticos complacentes de disseminação cultural por intermédio de fascículos e revistas de lazer, voltados para a classe média, que vivia a euforia do milagre econômico. Nesse espaço, o jornalismo crítico fica em segundo plano.

Os anos de chumbo

A junta militar divulga o AI-12, proclamando-o em cadeia de televisão, assim como a justificativa para o impedimento da posse do substituto natural, o vice-presidente Pedro Aleixo. Essa justificativa baseia-se na grave 
Normas para a apresentação de originais

Hegemonia - Revista Eletrônica de Relações Internacionais do Centro Universitário Unieuro

ISSN: $1809-1261$

UNIEURO, Brasília, número 14, 2014, pp. 131-171.

situação interna do país. Em 16 de setembro, a junta militar divulga nota oficial comunicando o afastamento definitivo de Costa e Silva. Em 27 de setembro, é publicado o Decreto-Lei no 898, colocando-se em vigor uma nova Lei de Segurança Nacional, estabelecendo-se que todo condenado à morte que não tivesse sua pena comutada em prisão perpétua pelo Presidente da República, em trinta dias, seria fuzilado. $O$ controle sobre a imprensa é intensificado: seria preso o jornalista que divulgasse notícias "falsas ou tendenciosas" ou fatos verídicos "truncados ou desfigurados".

O general Emílio Garrastazu Médici não tem unanimidade nos setores militares. Ele é uma das cabeças da Hidra. Assim, em 14 de outubro, é editado o AI-17 (que viria a ser o último editado pelo regime militar), em que a junta é autorizada a transferir para a reserva os militares que "houvessem atentado ou viessem a atentar, comprovadamente, contra a coesão das forças armadas", revelando-se, dessa forma, elementos de oposição ao nome do general Médici no interior da tropa (Vera Calicchio/Dora Flaksman, CPDOC-FGV, 2004).

Em 25 de outubro, Médici é eleito pelo Congresso e, em 30 do mesmo mês, empossado. Em dezembro, a revista Veja, aproveitando-se de uma declaração descuidada do presidente, de que, no seu governo, não admitiria torturas, publica duas reportagens, em sequencia, denunciando a tortura de presos políticos e anunciando a preparação de um dossiê nacional que seria entregue ao presidente. Veja fica isolada na denúncia. De acordo com Kucinsk (2003), os jornais de circulação nacional ficaram mudos. Toda a equipe que produziu as reportagens teve de sair da revista. Fechava-se o último espaço para um jornalismo crítico.

Com o governo Médici, esgotam-se as lutas abertas e as clandestinas contra o regime, simbolizadas pelas mortes de Carlos Marighella, em 1969, e de Carlos Lamarca, em 1971, e pela derrota da guerrilha do Araguaia. A esses fatos, aliou-se a dramática derrubada do governo Allende, no Chile, em 1973. A oposição legal cai em estado de apatia. A imprensa resvala para o colaboracionismo aberto, divulgando notícias plantadas pela polícia sobre fugas ou atropelamentos de presos políticos. Todos, indiscriminadamente, são apontados como terroristas e a imprensa torna-se 
Normas para a apresentação de originais

Hegemonia - Revista Eletrônica de Relações Internacionais do Centro Universitário Unieuro

ISSN: $1809-1261$

UNIEURO, Brasília, número 14, 2014, pp. 131-171.

cúmplice dos assassinatos desses presos. As denúncias de tortura ecoam nos jornais internacionais. Mas os jornais brasileiros como $O$ Globo, $O$ Estado de São Paulo e Folha de São Paulo, em seus editoriais, negam as acusações, atribuindo-as a campanhas de difamação do regime (ibid., 2003).

Nos anos seguintes, vemos as classes dominantes brasileiras darem a maior demonstração de servidão cívica, só tendo sido vista situação semelhante no Império. O governo Médici fecha o Congresso, cassa mandatos, extingue o instituto do habeas-corpus e infringe dura censura à imprensa, com a conivência das nossas elites. É o outro jogo do terceiro presidente da revolução. Felizmente, segundo Márcio Moreira Alves, um punhado de homens e mulheres, saídos de todos os extratos da sociedade, conservou vivo o sonho da liberdade e da democracia. Sedimentaram-se as concepções das hordas militares radicais. Segundo Chagas (1973), eram propagadas idéias de que 0 regime de exceção deveria durar indefinidamente no país, como garantia de seu desenvolvimento.

\section{O Pasquim - a era do humor}

Os pequenos jornais, na sua maioria "imprensa alternativa", são referidos por Fontcuberta e Mompart (1983) como vinculados à esquerda num "sequestro semântico". Esse elo simbiótico é entendido da mesma maneira pelos militares. Dessa forma, todos os veículos alternativos têm seus editores cassados ou perseguidos e são impedidos de circular. Entre ele, podemos incluir a chamada imprensa comunitária e os jornais de categoria profissional, que não escapam à fúria da polícia e dos censores. $O$ encolhimento dos jornais "sérios", ocorrido a partir do Ato Institucional número 2, assinala a fase de criatividade dos profissionais da imprensa ligados ao humor, embora seja, também, o prenúncio do endurecimento que viria com o AI-5.

Confirmando essa fase criativa do jornalismo de humor, $O$ Pasquim lança, em 26 de junho de 1969, seu primeiro número. Imaginado, inicialmente, por Jaguar, seu principal idealizador, para ser um jornal do bairro de Ipanema, do Rio de Janeiro, ele universaliza-se e transforma-se na visão crítica absorvida por jovens e intelectuais do país inteiro. 
Normas para a apresentação de originais

Hegemonia - Revista Eletrônica de Relações Internacionais do Centro Universitário Unieuro

ISSN: $1809-1261$

UNIEURO, Brasília, número 14, 2014, pp. 131-171.

0 Pasquim revolucionou a linguagem do jornalismo brasileiro, instituindo uma oralidade que ia além da mera transferência da linguagem coloquial para a escrita do jornal. Essa revolução, semi-apreendida pela imprensa nos anos seguintes, teve impacto mais profundo na publicidade. (Kucinski, 2003, p. 210).

Com essa forma de fazer jornal, $O$ Pasquim chega a vender duzentos mil exemplares. $O$ jornal consegue penetração entre os filhos da classe média. Isso não agrada o governo repressor, que estabelece a tese de que "o jornal é um instrumento de grupos subversivos com o objetivo de destruir a família brasileira". Assentado na sua doutrina de Segurança Nacional, o governo baixa, em 1970, o Decreto-Lei 1.077, que revigora a censura prévia de cunho político, com abrangência para a censura de cunho moral, considerando que "as publicações e exteriorizações contrárias à moral e aos bons costumes obedecem a um plano subversivo que põe em risco a segurança nacional" (Kucinsk, 2003, p. 216).

Para Kucinsk, apesar de toda a repressão exercida pelos militares, surgiram, depois de 1968, vários jornais alternativos "não-integrados" ao sistema que, de acordo com a Teoria Crítica, não aceitam a estandardização ou a "normalização" da notícia imposta pelo golpe militar (Alves, 2002, p.9): Bondinho, 1971; Politika, 1971; Opinião, 1972; Ex, 1973. De todos, ainda segundo Kucinski, $O$ Pasquim foi a experiência mais bem sucedida de jornal alternativo daquele período. Para ele, os jornais alternativos dos anos 70 surgiram na forma de gerações superpostas. A primeira, protagonizada basicamente pelos derrotados de 1964. A última, formada por jovens pioneiros do jornalismo pós-moderno do novo milênio.

Essa nova geração de veículos alternativos, feitos por profissionais de forma regional, emerge da crise da grande imprensa "integrada ao sistema", em virtude do assassinato do jornalista Vladimir Herzog, em outubro de 1975. É quando se dá a diversificação temática e espacial da imprensa alternativa. Essa mudança vai influir, decisivamente, no comportamento da grande imprensa em relação à luta pela abertura do regime militar. Até esse momento, jornais como Folha de São Paulo e o Estadão, que somente após a edição do AI-5 toma uma 
Normas para a apresentação de originais

Hegemonia - Revista Eletrônica de Relações Internacionais do Centro Universitário Unieuro

ISSN: $1809-1261$

UNIEURO, Brasília, número 14, 2014, pp. 131-171.

posição digna, eram anódinos, inexpressivos, comportando-se da maneira mais complacente possível, aceitando docilmente as determinações militares (Gentilli, 2004).

\section{A abertura}

O ano de 1977 pode ser considerado a chave do processo de abertura. A ditadura vinha sofrendo sérios abalos intestinos desde 1974, o que leva o estado-maior militar, de maioria castelista, a optar pela política de abertura. Essa decisão é contestada pela linha-dura do regime comprometida com a repressão. É a "Hidra de Lerna" manifestando-se e abrindo nova crise no núcleo militar, o que vai afetar, profundamente, a grande imprensa e sua política de adesismo ao sistema. Os maiores jornais ficam na expectativa acerca de qual será o ditador de plantão que irá substituir o "duro" Emílio Médici, para definirem suas linhas editoriais (ibid., p.10).

Ernesto Geisel, quarto presidente do ciclo militar, é empossado em 15 de março de 1974. Logo no início de seu governo, enfrenta dificuldades que marcam o fim do "milagre brasileiro" e ameaçam a estabilidade do regime. Contribui para essa situação a recessão da economia do capitalismo mundial, que enfrenta a crise internacional do petróleo. Isso vai refletir na economia brasileira com o aumento das taxas de juros e a redução do crédito, que coloca a dívida externa brasileira em patamares críticos.

Com o anúncio do processo de abertura política "lento, gradual e seguro", o presidente Geisel, nos bastidores do poder, procura isolar e afastar, dos postos de comando e dos órgãos de repressão, os militares da linha-dura. Ao mesmo tempo, a burguesia industrial brasileira, sentindo propício o momento, assume o processo de ruptura, com o objetivo de bloquear a política de estatização como solução natural do governo militar e abrir espaço para o neoliberalismo (Kucinski, 2003). Nesse processo, a oposição ganha forças e o MDB - Movimento Democrático Brasileiro - sigla política que abrigava a maioria da esquerda - consegue quase $60 \%$ dos votos para o Senado e cerca de $48 \%$ 
Normas para a apresentação de originais

Hegemonia - Revista Eletrônica de Relações Internacionais do Centro Universitário Unieuro

ISSN: $1809-1261$

UNIEURO, Brasília, número 14, 2014, pp. 131-171.

para a Câmara dos Deputados, vencendo em 79 das 90 cidades com mais de 100 mil habitantes.

A censura à imprensa é suspensa em 1975. Com essa medida, Geisel e Golbery iniciam o processo de volta gradual ao estado de direito. 0 grupo da linha-dura que ainda resiste e vê esse processo como retrocesso nos ideais do movimento de abril de 1964, desencadeia, em resposta, uma onda de repressão contra membros e simpatizantes do Partido Comunista Brasileiro $(\mathrm{PCB})$, entre os quais um grande número de jornalistas. Os assassinatos de Vladimir Herzog, em outubro de 1975, e do operário Manuel Fiel Filho motivam grandes manifestações da sociedade civil contra a violência da ditadura militar. Os sinais de vida da sociedade organizada tornam-se cada vez mais visíveis e demonstram que o caminho rumo à redemocratização é irreversível.

A liberalização da imprensa é parte fundamental do processo de abertura concebido por Geisel e Golbery. Eles sabem que esse é o primeiro passo importante no plano político para derrotar a linha-dura, assim como a imprensa "colaboracionista" foi importante para a derrota rápida dos grupos de luta armada que utilizavam métodos violentos. $\mathrm{O}$ abrandamento da censura e da autocensura passa a ser a forma mais breve e eficaz de se intimidar os aparelhos de repressão que reagem à abertura (Kucinski, 2003).

Estão, assim, criadas as condições para se liquidar o excesso de cabeças da "Hidra de Lerna". O presidente Geisel demite o general linha-dura Ednardo D'Avila de Melo. Mas as lutas intestinas no aparelho militar duram ainda quase dois anos, até a demissão do ministro do Exército, general Silvyo Frota, no final de 1977. Para conter descontentamentos com essa medida, Geisel provoca um retrocesso no plano de abertura e permite algumas cassações de mandatos, mantendo, assim, o controle do processo.

Em abril de 1977, o governo decreta o recesso do Congresso e baixa o chamado "Pacote de Abril". As regras eleitorais são modificadas de modo a garantir maioria parlamentar ao partido do governo, a Aliança Renovadora Nacional (Arena). O mandato presidencial é ampliado de cinco para seis anos. E é criada a figura do Senador biônico, que seria eleito indiretamente pelas Assembleias Legislativas estaduais. É exigido o expurgo de jornalistas das 
Normas para a apresentação de originais

Hegemonia - Revista Eletrônica de Relações Internacionais do Centro Universitário Unieuro

ISSN: $1809-1261$

UNIEURO, Brasília, número 14, 2014, pp. 131-171.

redações da grande imprensa, pois muitos donos de jornal, como Otávio Frias, do Folha de São Paulo, ainda acreditam e apostam na posse do general Sylvio Frota como novo presidente de plantão. Frias redefine a linha editorial do jornal, demite Cláudio Abramo e coloca em seu lugar Boris Casoy, mais afinado com a linha-dura militar. Outros, dos principais quadros dirigentes da grande imprensa, são demitidos (Kucinski, 2003, p.100).

Em 1978, Geisel envia ao Congresso uma emenda constitucional que termina com o AI-5 e restaura o instituto do habeas-corpus. Essa medida abre caminho para a normalização da vida política do país. Entende o presidente Geisel e o grupo castelista do governo que as razões internas que levavam à abertura "lenta, segura e gradual", como ele prometera no seu discurso de posse, estavam no fato de o regime militar, nos dez anos de poder, ter eliminado todo e qualquer movimento de contestação: a articulação civil em torno do projeto da Frente Ampla, de Juscelino, Lacerda e João Goulart, foi superada com a cassação do seu principal articulador, Carlos Lacerda; a revolta estudantil, de 1968, foi desbaratada com a edição do AI-5; as guerrilhas urbana e rural e a do Araguaia, organizada pelo $\mathrm{PC}$ do $\mathrm{B}$, foram liquidadas pela intensa mobilização militar, entre 1971 e 1972 (CPDOC-FGV, 2004).

Outra questão que pesa na avaliação de Geisel e Golbery é o reconhecimento da anarquia reinante nos quartéis. Cada comandante domina sua área como um feudo e exige ampla liberdade para combater a subversão, cada um a seu modo. Para os dois generais, essas posições radicais da linhadura mancham a imagem do Brasil no exterior, além de, progressivamente, afastar as elites e a classe média do núcleo de apoio civil ao regime militar.

O governo Figueiredo e o terrorismo

Nas eleições de 1978, o crescimento das oposições acelera o processo de abertura política. 0 general João Baptista de Oliveira Figueiredo toma posse em 15 de março de 1979 e concede anistia aos acusados ou condenados por crimes políticos. Em dezembro, muda a lei eleitoral e partidária, restabelecendo o pluripartidarismo. O grupo da linha-dura, ainda 
Normas para a apresentação de originais

Hegemonia - Revista Eletrônica de Relações Internacionais do Centro Universitário Unieuro

ISSN: $1809-1261$

UNIEURO, Brasília, número 14, 2014, pp. 131-171.

com sobrevida, tenta perturbar o processo e executa vários atentados a bomba contra instituições democráticas, como o ocorrido contra a Ordem dos Advogados do Brasil (OAB) e o mal sucedido atentado terrorista ao Centro de Convenções do Riocentro, em 30 de abril de 1981, por ocasião de um show comemorativo do Dia do Trabalho.

Para que possa levar, até o final, o processo de abertura, o presidente Figueiredo recebe o mais longo mandato de todos os presidentes do ciclo militar: seis anos. Seu governo tem reflexos diretos na crise econômica, de 1981 a 1984, e nas disputas internas do núcleo palaciano, devido à inabilidade política do presidente.

O movimento pela anistia havia começado na segunda metade da década de 70, reunindo entidades do movimento estudantil e sindical, organizações populares, Igreja, ABI e OAB. Mas a grande imprensa, embora esteja a favor da proposta, não a defende na mesma linha das forças populares e dos partidos políticos. O jornal O Estado de São Paulo, no editorial "A anistia e a esperança", mostra seu posicionamento expressando: "o que se supunha ser a primeira etapa no caminho da reconciliação pode acabar em mais um motivo de divisão e acirramento dos ânimos", uma clara posição de "ameaça" do jornal como elemento de intermediação com a sociedade. Para o Estadão, a esperança em torno da anistia não se justifica e ele responsabiliza a liderança governista na Câmara dos Deputados que, na sua opinião, quer transformar a anistia em "instrumento de clientelismo e de distinção social". Segundo o jornal, pretende-se incluir na lei crimes que não são expressamente políticos (CPDOCFGV, 2004).

Em agosto de 1979, é aprovada a Lei de Anistia. O que foi uma bandeira de luta das forças populares acaba sendo apropriada pelos golpistas civis e militares torturadores. A abrangência da lei, "ampla e irrestrita", veio beneficiar também os que poderiam sofrer penalidades por abuso de poder, tortura e mortes no período de exceção. Assim, os que exerceram a ação do ato de arbítrio ficam cobertos pela lei, em igualdade de condições com os que sofreram a ação do ato de arbítrio. Dessa forma, são anistiados os acusados de crimes políticos e os conexos, ou seja, tanto os adversários do regime militar 
Normas para a apresentação de originais

Hegemonia - Revista Eletrônica de Relações Internacionais do Centro Universitário Unieuro

ISSN: $1809-1261$

UNIEURO, Brasília, número 14, 2014, pp. 131-171.

quanto os opressores e torturadores, ficando de fora os acusados de "atos terroristas." (ib., 2004).

"Diretas Já" e a grande imprensa

Os partidos de oposição iniciam a campanha "Diretas Já", em novembro de 1983, visando uma emenda constitucional que permita a eleição do Presidente da República pelo voto popular em 1984. Esse movimento transforma-se no maior movimento de massa da história do Brasil. Nesse clima de intensa luta pela democracia de fato e de direito, é apresentado projeto de emenda, pelo deputado Dante de Oliveira, que leva o seu nome e restabelece as eleições diretas para a presidência da República. Não obstante a grande mobilização da população brasileira, a emenda é rejeitada pelo Congresso e a escolha do novo presidente é pela via indireta, por meio do Colégio Eleitoral.

A campanha "Diretas Já" não é encampada por toda a grande imprensa. $O$ único jornal que se posiciona, desde o início, favoravelmente a ela é o Folha de São Paulo que, em plena efervescência da campanha, fica na defesa do movimento. Os demais estão à espera, para ver de que lado sopra o vento do Palácio do Planalto. Depois do sucesso do comício de 25 de janeiro, na praça da Sé, em São Paulo, a campanha não pode mais ser ignorada pela mídia e a grande imprensa engaja-se no movimento.

O Folha lança o lema "Amarelo sim", que exorta a população a usar o amarelo como símbolo da campanha. Na verdade, essa posição mostra a imprensa como aparelho privado de hegemonia e como ator político/ideológico da campanha, à medida que ela tenta claramente orientar, dirigir (Fonseca, 2003, p.8) o movimento para posições contrárias as dos grupos que lideram o processo, quando propõe "afastar corajosamente as nuances do espectro político para abraçar apenas uma delas". Os partidos terminam por abraçar a idéia, acrescentando a cor verde ao amarelo proposto pelo jornal. E a campanha das "Diretas Já" inunda o país, de norte a sul, de verde e amarelo. 
Normas para a apresentação de originais

Hegemonia - Revista Eletrônica de Relações Internacionais do Centro Universitário Unieuro

ISSN: $1809-1261$

UNIEURO, Brasília, número 14, 2014, pp. 131-171.

Como o Partido Democrático Social (PDS), de sustentação do governo, ganha em 12 Estados com certa facilidade, o presidente Figueiredo não cria dificuldades para realização da eleição para presidente, mesmo que indireta, talvez na esperança de se eleger um candidato de sua confiança, comprometido com o movimento de abril de 1964. Em 15 de janeiro de 1985, Tancredo Neves é eleito Presidente da República, tendo José Sarney como vice, ambos pelo Colégio Eleitoral. Tancredo vence Paulo Maluf por 480 votos a favor, contra 180 e 26 abstenções. Antes, em novembro de 1980, fora aprovada a emenda constitucional estabelecendo as eleições diretas para Governador.

Novas cisões no núcleo do poder terminam por provocar o afastamento do general Golbery da chefia da Casa Civil, substituído por Leitão de Abreu, que já havia ocupado o cargo no governo Médici. Os "tropeiros" linha-dura dão o troco ao ideólogo do golpe e da abertura. Mas a ditadura militar, depois de 21 longos anos, chega ao fim.

Tancredo Neves é o grande articulador da transição que, ao contrário das suas expectativas, não ocorre de forma pacífica. $O$ grupo da linhadura, até o último momento, trabalha para impedir que o país volte à normalidade democrática. A jogada decisiva da cabeça reacionária da "Hidra de Lerna" é o apoio à candidatura de Paulo Maluf no Colégio Eleitoral, proposta liderada pelo ministro Délio Jardim de Mattos com o Alto Comando da Aeronáutica. Aí, prevalece o espírito conciliador do político mineiro, segundo o general da reserva Otávio Costa, interlocutor de Tancredo no Exército, em declaração ao jornalista Hélio Contreiras do Correio Braziliense:

Tancredo evitou que os radicais virassem a mesa e patrocinassem uma onda de violenta repressão. Ao mesmo tempo, impediu que houvesse uma radicalização política capaz de levar militares acusados de prática de violências contra presos políticos ao banco dos réus $(C B, 13$ de set.,Seção Política, p. 4)

Os militares moderados estão conscientes de que a eleição de Paulo Maluf causará problemas políticos e uma possível rejeição popular de grande porte, bem como rejeição no próprio Congresso, em virtude da grande mobilização pelas eleições diretas, em defesa da Emenda Dante de Oliveira. 
Normas para a apresentação de originais

Hegemonia - Revista Eletrônica de Relações Internacionais do Centro Universitário Unieuro

ISSN: $1809-1261$

UNIEURO, Brasília, número 14, 2014, pp. 131-171.

Além disso, segundo o general Ivan de Souza Mendes, em entrevista ao $C B$, o passado de Maluf é controverso e ele enfrentará problemas de governabilidade por causa de uma forte rejeição no Congresso.

Para o general Souza Mendes, o regime durou mais do que havia sido esperado e mais do que muitos teriam desejado. Os radicais, depois de serem derrotados, em setembro de 1984, com a decisão do alto comando militar, que não concordou com o retrocesso político, sofrem a penúltima derrota - a última seria no Colégio Eleitoral - quando o Tribunal Superior Eleitoral decide que a fidelidade partidária não se aplica ao Colégio Eleitoral.

Tancredo Neves/José Sarney

Em 14 de março de 1985, véspera da posse, o presidente eleito Tancredo Neves é internado no Hospital de Base de Brasília. Sarney assume o governo com a morte de Tancredo em 21 de abril, sustentado pela forte liderança do general Leônidas Pires Gonçalves, que havia sido indicado ministro do Exército por Tancredo. Ele defende a tese de que José Sarney deve assumir o cargo de presidente, o que demonstra que o primeiro governo civil, depois de 20 anos de regime de exceção, tem como eminência parda e respaldo um homem fardado com cinco estrelas.

A história política brasileira, do início dos anos 60 ao final de 1980, foi marcada pelo aparecimento e pelo fim do regime autoritário militar, que perdurou 21 anos. Para Vizentini, esse período alterou de forma profunda a sociedade brasileira:

basicamente, o regime militar propôs-se e cumpriu dois objetivos básicos: construir um moderno capitalismo industrial e conter o movimento popular. Quanto ao primeiro aspecto, é preciso considerar que os militares deixaram o Brasil na posição de único país ao sul do Equador dotado de um completo e diversificado parque industrial, ao contrário de seus congêneres do Cone sul, que desindustrializaram seus países (Vizentini, 2003, p.72). 
Normas para a apresentação de originais

Hegemonia - Revista Eletrônica de Relações Internacionais do Centro Universitário Unieuro

ISSN: $1809-1261$

UNIEURO, Brasília, número 14, 2014, pp. 131-171.

Mas, na verdade, esse projeto não havia revertido a dependência do país, que continuou sufocado por uma dívida externa que estrangulou a economia causando uma série de distorções.

A eleição de Tancredo Neves, em 1985, apesar de indireta, traz entusiasmo à maioria dos brasileiros. Ele recebe o apoio do conjunto das oposições, exceto do PT. Sua morte comove e causa na população grande temor de que os militares retornem ao poder. Considerando-se que Tancredo não havia tomado posse oficialmente, essa situação força um acordo pelo alto. Sarney é respaldado pelos militares e assume a Presidência da República.

Os setores da direita radical do regime optam, para concorrer à sucessão do general Figueiredo, pelo nome de Paulo Maluf, um civil do PDS, partido que sustenta o governo, embora esteja com suas bases divididas. Maluf, de perfil corrupto, representa um perigo para a consolidação da transição e da democracia, assunto que é explorado com habilidade pela imprensa. Com isso, cria-se um clima de radicalização e medo na população e, ainda para Vizentini (2003, p.67) "propiciando as bases para uma solução política negociada para o impasse, ao que se agregava o sempre presente temor de uma reação dos militares em caso de vitória da tese das 'Diretas Já".

Considerações Finais

A transição para a Nova República idealizada por Tancredo Neves traz dois importantes aspectos no seu bojo, inerentes a RUPTURA e CONTINUIDADE.

A ruptura leva ao fim do regime político autoritário e de exceção, amplia o processo político representativo, com a eleição direta para Presidente da República, o retorno ao pluripartidarismo político eleitoral e a realização de uma nova Assembleia Nacional Constituinte.

A continuidade destaca-se: por ter sido a transição realizada pelo alto, isto é, por ela não ter sido objeto de mobilizações populares intensas e 
Normas para a apresentação de originais

Hegemonia - Revista Eletrônica de Relações Internacionais do Centro Universitário Unieuro

ISSN: $1809-1261$

UNIEURO, Brasília, número 14, 2014, pp. 131-171.

organizadas; pelo enraizado clientelismo político, com o consequente empreguismo; pela permanência dos militares em cargos-chaves do Estado; pela manutenção do Serviço Nacional de Informação (SNI); pela continuidade das elites tradicionais e de políticos do partido de apoio ao regime militar (Arena) em posição de mando na estrutura do Estado e na Assembleia Nacional Constituinte.

A ruptura e a continuidade são fatores determinantes para uma transição difícil e demorada. Nos acordos firmados, as Forças Armadas desejam sair do poder da maneira mais confortável possível, levando-se em conta que essas instituições ficaram manchadas em virtude de questões dos direitos humanos, como a tortura. Esses aspectos de ruptura e continuidade são, na opinião de Bresser Pereira, o resultado do "colapso do pacto autoritário capitalista-tecnicoburocrático, a partir dos meados dos anos 70", que viria a ser substituído pelos "pactos políticos possíveis depois da redemocratização".

Em toda essa movimentação política, a grande imprensa tem atuação diferenciada. A

Folha de São Paulo, segundo Cláudio Abramo, (1984, pp.119/120), seu diretor à época, afirma que se tornou um jornal muito aberto nesse período. (...) 0 Estado é contra a reforma agrária, contra a igreja progressista, contra o fim da Lei Segurança Nacional, quer o predomínio da burguesia no Congresso, mas, mesmo assim, começa a entrar em choque com suas próprias concepções. $\grave{E}$ contra a Censura - ainda que não tenha se manifestado com a mesma veemência da Folha -, mas não acha muito bom Lula ter quinze minutos para falar no horário da propaganda eleitoral, ou que Leonel Brizola também tenha esse tempo.

Nessa análise percorremos a trajetória da imprensa, desde o seu aparecimento no início do século XIX, com a vinda de D. João VI para o Brasil, até o limiar do século XXI. Nesse percurso, a imprensa brasileira passou por diversas fases: o seu surgimento como imprensa áulica a serviço da colonização portuguesa; os momentos de insurreição dos pasquins, combatentes contra a dominação colonial, em que se enfrentou o fechamento total; alguns momentos de liberdade controlada pelo Estado; até sua transformação em empresa dentro do sistema capitalista, tornando-se um instrumento da corrente hegemônica 
Normas para a apresentação de originais

Hegemonia - Revista Eletrônica de Relações Internacionais do Centro Universitário Unieuro

ISSN: $1809-1261$

UNIEURO, Brasília, número 14, 2014, pp. 131-171.

desse sistema. Apesar da sua transformação em linha de sustentação do poder, em virtude das próprias contradições inerentes ao sistema capitalista, ela sofreu em vários momentos da sua história períodos de repressão e censura.

Foi assim nas lutas contra a escravatura e pela independência; na queda da Velha República e no Estado Novo varguista. E, mais recentemente, com o golpe de 1964, quando o regime militar, em contradição com o pensamento de amplos setores populares e da pequena burguesia brasileira, impôs à imprensa um longo período de mordaça.

Nesse contexto histórico, voltou a surgir a imprensa alternativa de resistência e os jornais comunitários-corporativos. Esses veículos representavam a contracorrente ao poder hegemônico e procuravam dar voz àquelas parcelas da sociedade que, reprimidas, não tinham instrumentos de mediação social diante do poder dominante.

Como no passado, esse tipo de imprensa foi fundamental no processo de luta contra o arbítrio, tendo em vista que a grande imprensa, apesar das contradições interclasses, continuava sendo o espaço de voz das classes dominantes e, como parte integrante dessas classes, amoldava seus discursos ao poder, que, afinal, era da sua própria classe.

De 1964 até 1970, mesmo com o espaço de voz reduzido pela repressão, os jornais de resistência conseguiram proferir um discurso dentro de uma linha crítica sem sujeição e não integrada ao sistema. 0 exemplo mais marcante dessa fase foi o jornal $O$ Pasquim. Mesmo numa posição de contracorrente da hegemonia, conseguiu ser 0 emissor que se propôs a construir escutas para seus receptores, que permitiu ser explicitada a diferença da relação entre o discurso funcionalista-integrado da grande imprensa e 0 discurso crítico de resistência.

A partir de 1970, quando a luta da sociedade por democracia forçou o regime militar a promover a distensão política, a relação de forças, distinguida como lugar e posição do discurso, e a formulação discursiva dos jornais alternativos de resistência contra a ordem constituída, já não faziam sentido. Nesse momento, surgiram com mais força os jornais comunitários-corporativos, de categorias profissionais, étnicas e de gênero. Grande parte da sociedade 
Normas para a apresentação de originais

Hegemonia - Revista Eletrônica de Relações Internacionais do Centro Universitário Unieuro

ISSN: $1809-1261$

UNIEURO, Brasília, número 14, 2014, pp. 131-171.

começou a construir seus próprios mecanismos de interlocução e de intermediação.

Esse novo contexto político influiu não só na imprensa alternativa, mas, também, na música, na literatura e nas artes em geral. A produção artística, jornalística e literária voltada para a resistência perdeu o sentido prático.

A ação política passou a ser a busca da consolidação das liberdades e da democracia vislumbrada com a "abertura política". Com a instalação da Assembleia Nacional Constituinte, categorias profissionais e setores organizados da sociedade passaram a construir seus próprios meios de intermediação política e social, para suprir o espaço de voz que a grande imprensa negou-lhes no processo constituinte e passaram a defender os interesses das classes a que pertenciam.

\section{REFERÊNCIAS BIBLIOGRÁFICAS}

ABRAMO, Cláudio. As Regras do Jogo, São Paulo, Cia. das Letras, 1988.

ALVES, Márcio Moreira. 68 Mudou o mundo, Rio de Janeiro, Nova Fronteira. 1993.

ALVES, Sandro. Teorias da comunicação, Brasília, UnB/IDA, 2003.

ARAÚjO, Ellis Regina e SOUZA, Elizete Cristina de, Obras Jornalísticas: uma

Síntese, Brasília, Westcom, 2003.

CASTRO, Celso e D'ARAUJO, Maria Celina. Militares e política na Nova República, Rio de

Janeiro, FGV Editora, 2001.

CHAGAS, Carlos. Resistir é preciso, Rio de Janeiro, Paz e Terra, 1975.

FOUCAULT, Michel. $A$ ordem do discurso - $8^{a}$ ed. - Edições Loyola, São Paulo, 2002. 
Normas para a apresentação de originais

Hegemonia - Revista Eletrônica de Relações Internacionais do Centro Universitário Unieuro

ISSN: $1809-1261$

UNIEURO, Brasília, número 14, 2014, pp. 131-171.

FRANÇA, Vera Regina Veiga. Construção jornalística e dizer social, in O jornal: da forma ao sentido, org. Maurice Mouilland \& Sérgio Dayrell Porto, Brasília, Edit. UnB, 2002

GASPARI, ELIO. A Ditadura Escancarada, São Paulo, Cia. das Letras, 2002

GENTILLI, Vitor. Sistema midiático e crise do jornalismo: crônica da história política brasileira, São Paulo, Edusc, 2002.

HOHLFELDT, Antonio / BARBOSA, Marialva, Org.- Jornalismo no século XXI: a cidadania, Porto Alegre, Mercado Aberto, 2002.

KOSHIBA, Luiz. História do Brasil, São Paulo, Editora Atual, 2000

KUCINSKI, Bernardo. Jornalistas e revolucionários: nos tempos da imprensa alternativa, 2ª ed., São Paulo, Editora Universidade de São Paulo, 2003.

ORLANDI, Eni Puccinelli. Análise de discurso: Princípios e Procedimentos, Campinas, Pontes, 5 a Edição, 2003.

RAMOS, Murilo César. $A$ agenda proibida: Meios de Comunicação e Revisão Constitucional, Brasília, Universidade e Sociedade, ANDES, 1993.

RODRIGUES, Edgar. Pequena história da Imprensa Social no Brasil, Florianópolis, Editora Insular, 1997.

SILVA, Martins Luiz da. Teorias da comunicação no século XX, Brasília, Casas das Musas, 2002.

Comunicação pública, Brasília, Casa das Musas, 2003.

SOUZA, Maria Campello de. Democratizando o Brasil. Org. Alfred Stepas, Rio de Janeiro, Paz e Terra, 1988.

SODRÉ, Nelson Werneck. História da imprensa no Brasil, $4^{a}$ ed., Rio de Janeiro, Mauad, 1999.

VIZENTINI, Paulo Fagundes. Relações internacionais do Brasil: de Vargas a Lula, São Paulo, Editora Fundação Perseu Abramo, 2003.

WOLF, Mauro. Teorias da comunicação, $1^{a}$ ed., Lisboa, Editorial Presença, 1999. 
Normas para a apresentação de originais

Hegemonia - Revista Eletrônica de Relações Internacionais do Centro Universitário Unieuro

ISSN: $1809-1261$

UNIEURO, Brasília, número 14, 2014, pp. 131-171.

REVISTAS INSTITUCIONAIS:

FONSECA, Francisco. O conservadorismo Patronal da grande imprensa, Campinas, Opinião

Pública, vol. 09, nº 02, out, 2003.

FONSECA, Thaís Nívea de Lima e. Revista Brasileira de História, vol. 2, no 44, São Paulo, 2002.

LANER, Vinícius Ferreira. A Lei de Imprensa no Brasil, Terezina, Jus Navigandi, a. $5, \mathrm{n}^{\circ} 18, \mathrm{dez}, 2000$.

LEITE, Rosalina Santa Cruz. Brasil Mulher e Nós Mulheres: origens da imprensa feminista Brasileira, Florianópolis, Ver. Estud. Fem., vol. 11, no 1, 2003.

MUZART, Zahidé lupinacci. Uma espiada na imprensa das mulheres no século $X I X$,

Florianópolis, Revista Estudos Feministas, vol. 11, nº 01, 2003.

NJAINE, Katie e MINAYO, Maria Cecília de Souza. Análise do discurso da imprensa em Regime de privação de liberdade, Rio de Janeiro, Ciência, Saúde coletiva, vol. 07, nº 02, 2002.

PEREIRA, Bresser. Pactos Políticos: do populismo à Redemocratização, São Paulo, Editora Brasiliense, 1985.

JORNAIS:

CONTREIRAS, Hélio. $A$ derrota da linha dura, Correio Braziliense, editoria de Política, p. 04, set. 2004.

D'ARAUJO, Maria Celina. O golpe estava na pauta da esquerda, entrevista a 0 Povo, editoria de Política, mar, 2004. 
Normas para a apresentação de originais

Hegemonia - Revista Eletrônica de Relações Internacionais do Centro Universitário Unieuro

ISSN: $1809-1261$

UNIEURO, Brasília, número 14, 2014, pp. 131-171.

DOCUMENTOS ELETRÔNICOS:

ABREU, Alzira Alves de. Revolução de 1964. http://www.fgv.br/ CPDOC-FGV. Acesso em: 10 agosto 2004.

CALICCHIO Vera, e FLAKSMAN, Dora. A junta militar. http://www.fgv.br/ CPDOC-FGV. Acesso em: 10 de agosto 2004.

CEPDOC-FGV. História dos Presidentes. http://www.fgv.br/CPDOC-FGV. Acesso em: 10 agosto 2004.

D'ARAUJO, Maria Celina. O governo Vargas. http://www.fgv.br/ CPDOC-FGV. Acesso em: 10 agosto 2004.

DIAS, Maurício. Revolução de 1964. http://www.fgv.br/ CPDOC-FGV. Acesso em: 10 agosto 2004.

SÃO PAULO, Folha de. 0 Estado Novo.

http://www1.folha.uol.com.br/folha/almanaque/memoria. Acesso em: 10 agosto 2004. 